\title{
Topical Ankaferd Bloodstopper in the Management of Critical Bleedings due to Hemorrhagic Diathesis
}

\author{
Mehmet TURGUT ${ }^{1}$, Ferda TUTKUN $^{2}$, Nükhet CELEBI ${ }^{2}$, Mehtap MUGLALI $^{2}$, \\ İbrahim C. HAZNEDAROGLU ${ }^{3}$, Hakan GOKER ${ }^{3}$ \\ ${ }^{1}$ Samsun 19 Mayis University Faculty of Medicine, Department of Hematology, Samsun \\ ${ }^{2}$ Samsun 19 Mayıs University, Faculty of Dentistry, Samsun \\ ${ }^{3}$ Hacettepe University Faculty of Medicine, Department of Hematology, Ankara, TURKEY
}

\begin{abstract}
Ankaferd BloodStopper ${ }^{\circledR}$ (ABS) is an herbal extract which has been used historically as a haemostatic agent in traditional Turkish medicine. ABS comprises of standardized mixture of herbs Thymus vulgaris, Glycyrrhiza glabra, Vitis vinifera, Alpinia officinarum and Urtica dioica. Basic effect mechanism of ABS is the formation of an encapsulated protein web which represents the focus points for the vital erythrocyte masses. The haemostatic effects have been demonstrated by in vitro and in vivo studies. The usage of ABS as a hemostatic agent in external hemorrhages and in dental treatment in humans constitutes the first hints on ABS's safety and efficacy in humans. A phase I randomized, double-blinded, cross-over, placebo controlled clinical study in healthy volunteers indicated the safety of ABS. The aim of this report is to depict hemostatic effects of $A B S$ in critical bleedings due to hemorrhagic diathesis, refractory to conventional measures in distinct clinical settings.
\end{abstract}

Keywords: Ankaferd, Bleeding, Hemostasis, Hemorrhagic diathesis

\section{ÖZET}

Hemorajik Diyatez Varlığında Gelişen Kritik Kanamalarda Topikal Ankaferd Bloodstopper Uygulamaları

Ankaferd Bloodstopper (ABS), geleneksel Türk tıbbında hemostatik ajan olarak kullanılmış bitkisel bir ekstrakttır. ABS, Thymus vulgaris, Glycyrrhiza glabra, Vitis vinifera, Alpinia officinarum ve Urticia dioica bitkilerinden hazırlanmış standart bir preparattır. ABS'nin temel hemostatik etki mekanizması vital eritroid aggregasyon için odak oluşturan enkapsüle bir protein ağı meydana getirmesidir. In vitro ve in vivo çalışmalarla ABS'nin hemostatik etkisi ortaya konulmuştur. ABS'nin eksternal kanamalarda ve dental tedavilerde etkin biçimde kullanımı klinik yararılığı üzerine ilk verileri oluşturmuştur. Randomize, çift kör, çapraz geçişli ve plasebo kontrollü faz I çalışma ile ABS'nin sağl|klı gönüllülerde güvenilirliği gösterilmiştir.

Bu çalışmanın amacı, değişik klinik durumlarda hemorajik diyatez varlığında bilinen standart yöntemler kanamayı durdurmada başarısız kaldığında yapılan ABS uygulamalarının hemostatik etkinliğini raporlamaktır.

Anahtar Kelimeler: Ankaferd, Kanama, Hemostaz, Kanama diyatezi 


\section{INTRODUCTION}

Ankaferd Blood Stopper (ABS) comprises a standardized mixture of the plants Thymus vulgaris, Glycyrrhiza glabra, Vitis vinifera, Alpinia officinarum and Urtica dioica. ${ }^{1}$ Each one of these herbs is effective over endothelium, blood cells, angiogenesis, cell proliferation, vascular dynamics, and mediators. ${ }^{2,3}$ The herbal extract has been used historically as a haemostatic agent in traditional Turkish medicine. ${ }^{4,5}$ The basic mechanism of action for ABS is the formation of an encapsulated protein network that provides focal points for vital erythrocyte aggregation. ${ }^{2,3} \mathrm{ABS}$-induced protein network formation with blood cells particularly erythrocytes covers the primary and secondary haemostatic system without disturbing individual coagulation factors. This unique mechanism provides advantage to ABS, compared with other agents that have haemostatic effect. Exposure to ABS in a certain area provides physiological haemostatic process together with tissue oxygenisation, without calling out any individual coagulation factor. ${ }^{2,3,6,7}$ Göker and coworkers suggested that ABS causes an encapsulated protein web formation which will induce erythrocyte aggregation, affecting the fibrinogenerythrocyte agglutination relationship. ${ }^{3}$

There are distinct important molecular components of the Ankaferd-induced hemostatic network. Vital erythroid aggregation takes place with the spectrin ankrin and actin proteins on the membrane of red blood cells. Essential erythroid proteins (Ankrin recurrent and FYVE bundle containing protein 1, Spectrin alpha, Actin-depolimerisation factor, Actin-depolimerizing factor, LIM bundle and actine binding subunit 1 isoform a, LIM bundle and actine binding subunit 1 isoform $b$, NADP-dependent malic enzyme, NADH dehydrogenase (Ubiquinone) 1 alpha subcomplex, Mitochondrial NADP (+) dependent malic enzyme 3, Ribulose bisphosphatecarbocsilase large chain, Maturase $\mathrm{K}$ ) and the required ATP bioenergy (ATP synthase, ATP synthase beta subunit, ATP synthase alpha subunit, ATP-binding protein $\mathrm{C} 12$, $\mathrm{TP}$ synthase $\mathrm{H}+$ transporter protein, ADF, Alpha-1,2-glycosyltransferase ALG10A) are included in the protein library of Ankaferd. Ankaferd also upregulates GATA/FOG transcription system affecting erythroid functions and uroten$\sin$ II. ${ }^{1.8}$
ABS is a hemostatic agent that can be used effectively in the clinical practices, to control external bleedings, dental and periodontal hemorrhage, skin bleedings and/or superficial mucosal blood leakages. ${ }^{9-12}$ The haemostatic effects have been demonstrated by in vitro and in vivo studies. ${ }^{13-19}$ The usage of ABS as a hemostatic agent in external hemorrhages and in dental treatment in humans constitutes the first hints on ABS's safety and efficacy in humans..$^{10}$ A phase I randomized, double-blinded, cross-over, placebo controlled clinical study in healthy volunteers indicated the safety of ABS. The aim of this report is to depict hemostatic effects of ABS in critical bleedings due to hemorrhagic diathesis, refractory to conventional measures in distinct clinical settings.

\section{CLINICAL STATES OF HEMORRHAGIC DIATHESIS}

1. Topical ABS application in treatment of epistaxis refractory to thrombocyte transfusion during aplasic period after allogeneic stem cell transplantation in aplastic anemia

Allogeneic stem cell transplantation (AlloSCT) from a full compatible sibling is performed in a 20 years old female patient, who was already being followed for the last four years for serious aplastic anemia, since she did not respond to ATG/cyclosporine-A treatment. Epistaxis occurred in the patient on the 3rd day, by a decrease in the thrombocyte count around $10.000 / \mathrm{mm}^{3}$ after preparatory regime, due to the blood counts which were already low due to serious aplastic anemia even before the procedure. Epistaxis, which resulted in an additional decrease in haemoglobin counts, could not be controlled by 12 units of thrombocyte suspension, tamponade and, standard procedures, continued for more than 24 hours and has led to panic in the patient. After obtaining a verbal informed consent from the patient in this critical and uncontrollable bleeding with all known medical measures, patient agreed for local $2 \mathrm{~mL} \mathrm{ABS}$ is application for the severe epistaxis. Following ABS application, the bleeding has stopped in less than one minute. No side effect is observed. Although thrombocytopenia has persisted in the posttransplant period, epistaxis has not recurred in the patient. This patient is well with full-donor chimerism post-allogeneic hematopoie- 
tic transplantation. This is the first patient presented in English literature regarding ABS usage in haemorrhages accompanying AlloSCT.

2. Topical ABS application in treatment of oral bleeding infected lesions refractory to thrombocyte transfusion during aplasic period after chemotherapy in leukemia relapsed after AlloSCT

AlloSCT from a full compatible sibling was performed in a 26 years old male patient nine months ago, who was already being followed for the last two years for acute myeloid leukemia (AML-M4), since he responded to four courses of anthracyclin/Ara-C treatment. However, leukemia relapsed despite Grade II GVHD in due course and re-induction EMA chemotherapy was given leading to severe pancytopenia. Oral bleeding lesions with infected ulcers compatible with oral GVHD plus bacterial infection occurred in the patient on the 16th day following chemotherapy, by a decrease in the thrombocyte count to $3000 / \mathrm{mm}^{3}$. Bleeding severe mucositis which resulted in an additional decrease in cytopenias, could not be controlled by 10 units of thrombocyte suspension, antibacterial washes and, other standard procedures. After obtaining a verbal informed consent from the patient, locally $3 \mathrm{~mL}$ ABS was applied to the oral mucosa of the patient, since the bleeding and localized infection with Graft-versus-Host Disease (GVHD) could not be controlled with conventional methods. Following ABS application, the bleeding has instantly stopped and mucositis was healed within 2 days. No side effect is observed. Although neutropenia, anemia and thrombocytopenia has persisted in the aplasic period, mucositis has not recurred in the patient. This patient is still alive, and GVHD is now somewhat under control with steroids and immunosuppressive medications. This is the first patient presented in English literature regarding ABS usage in oral mucositis with bleeding lesions accompanying AlloSCT and chemotherapy.

3. Topical ABS application for the bleeding arteriovenous fistula in chronic renal failure with uremic platelet dysfunction

Seventy-year-old man with history of uremia was hospitalized for arteriovenous (AV) fistula revision. On the physical examination, moderate bleeding was observed from AV fistula. Laboratory findings revealed hemoglobine $8.2 \mathrm{~g} / \mathrm{dl}$, thrombocyte $56.000 / \mathrm{mm}^{3}$, D-Dimer $1341 \mathrm{microgram} / \mathrm{dl}$. Right jugular catheter was inserted for hemodialysis. Bleeding from the jugular catheter began after insertion. Despite the use of fresh frozen plasma, platelet infusions and mechanical compression, bleeding did not stop from the AV fistulae and the catheter border. Topical ABS which is approved for external bleeding lesions in Turkey, was applied externally to the AV fistula and catheter border. Hemorrhage was stopped immediately after the ABS application without any further bleeding.

\section{Topical ABS application for the bleeding dental- periodontal tissue in Glansmann thrombastenia}

Twenty-year-old woman with a history of Glanzmann thrombasthenia, was admitted to the hospital because of gingival bleed due to severe gingivitis. Periodontal therapy was applied. Spontaneous and periodontal therapy induced gingival bleeding was controlled with topical application of ABS. No platelet transfusion was done before and after procedure. One week later, ABS was applied to control the gingival bleeding, during the second periodontal therapy, and no platelet transfusion was required. After the effective periodontal therapy and ABS application, which is approved for dental bleeding in Turkey, to control the bleeding episodes, all the signs of severe gingivitis has disappeared and the patient recovered successfully.

\section{Topical ABS application for the bleeding dental- periodontal tissue in von Willebrand disease}

A woman with history of type III von Willebrand disease was examined by the dental surgeon due to the severe dental pain. Extraction of left mandibular 3rd molar and premolar teeth was decided, after her examination. She had a history of severe dental bleeding, despite the administration of fresh frozen plasma in her prior teeth extraction. Both teeth were extracted without any major bleeding, after ABS application.

\section{Topical ABS application for the bleeding dental surgery in Hemophilia-A}

Fifty-five year-old man with a history of haemophilia was admitted to the hospital because of severe 
dental pain. Extraction of right mandibular 3rd molar teeth was decided, after his examination. His aPTT (activate partial thromboplastin time) was 67 seconds, and his factor VIII level was $1.5 \%$. His teeth were extracted without any major bleeding, after topical ABS application. Six days after, he had a minor dental bleeding which stopped immediately after $\mathrm{ABS}$ administration with no more recurrences of bleed.

7. Topical ABS application for the bleeding pacemaker region in thrombotic cardiac disease with warfarin-induced coagulapathy

Sixty-five years old man who was chronically anticoagulated with coumadine was admitted to the hospital, because of atrio-ventricular complete block. One week before inserting the cardiac pacemaker, coumadine was stopped. Control INR ratio value was 1.1 , then the cardiac pacemaker was inserted. Immediately after the procedure, bleeding from the pacemaker was noticed. Bleeding was not controlled with the aplication of vitamin $\mathrm{K}$, fresh frosen plasma and local compression. Later, after the patient verbally informed and agreed with the ABS application, then ABS was applied to the bleeding area directly. The bleeding immediately stopped. During the follow up, no more bleeding was observed. Coumadin was started again, without any further bleeding.

8. Topical ABS application for the bleeding groin region in thrombotic cardiac disease with abnormal fibrinolysis due to tPA administration

In a 52 years old male patient to whom coroner angiography was applied due to coroner artery disease with serious coroner artery stenosis, systemic hyperfibrinolysis formed after intra coronary tPA application followed by secondary haemostatic disturbance after heparinization and the arterial bleeding appeared in groin area could be controlled by local application of ABS.

\section{DISCUSSION}

Topical hemostatic efficacy of ABS has been previously tested in animals with normal ${ }^{15,19}$ and defective hemostasis. ${ }^{16,20}$ Numerous studies demonstrated the haemostatic effects of topical ABS application in the animals with normal ${ }^{11,13,15,17,18}$ and defective hemostasis ${ }^{16,20}$ have set the preclinical stage for the development of this hemostatic product. Short-term hematological and biochemical safety of the oral systemic administration of Ankaferd to rabbits have been shown. ${ }^{14}$ Acute mucosal toxicity, hematotoxicity, hepatotoxicity, nephrotoxicity, and biochemical toxicity were not observed during the shortterm follow-up of the animals. ${ }^{14}$ Those preclinical results reflect a starting point to search any possible systemic confounding effect of ABS when applied to internal topical surfaces.

The usage of ABS as a hemostatic agent in external hemorrhages and in dental treatment in humans constitutes the first hints on ABS's safety and efficacy in humans. ${ }^{10}$ A phase I double-blinded, randomized, cross-over, placebo*controlled clinical study with a 5 days' wash-out period between the cross-over periods in healthy volunteers indicated the safety of ABS. Physiological cell-based coagulation could be clinically managed via topical ABS application to prevent and treat bleeding in many distinct clinicopathological states. ${ }^{11,19,21,22}$ The experience in the transplant patient shows that ABS application can be used safely in epistaxis control with antihaemorrhagic, haemostatic effectiveness. ABS effectiveness in other bleedings observed during AlloSCT course should be investigated.

The in vitro antibacterial activity of ABS was evaluated by Akkoç et al. ${ }^{23,24}$ In this study, the antagonistic activity of ABS is evaluated against 26 indicator strains consisting of 26 indicator strains Gram positive and Gram negative bacteria, in human and food pathogens, using agar diffusion method, and it is demonstrated that it is effective against all strains. Nisin, a food preservative bacteriosin used as a control, is found to be inactive against Gram negative strains. In addition to its high inhibitor activity against human and food pathogens, Gram positive and Gram negative bacteriae, it is observed that $\mathrm{ABS}$ is more stable than nisin in various temperatures and in the presence of enzymes. ${ }^{24}$ The antimicrobial activity of Ankaferd was tested against many pathogens. ${ }^{25}$ The isolates included A.baumannii, E. coli, $K$. pneumonia, $P$. aeruginosa, Enterobacter spp., Stenotrophomonas maltophilia, MRSA, methicillin resistant coagulase negative Staphylococcus, vancomycin susceptible Enterococcus and VRE. They have reported that Ankaferd was active 
against all these isolates, with zones of inhibition which were within the $10-18 \mathrm{~mm}$. diameter range. Antibacterial activities of Ankaferd against several gram positive and gram negative food and human pathogens, were also reported in another study. ${ }^{24}$ Consequently, in addition to its haemostatic effects in haemorrhagic wounds' healing, it is pointed out that its antimicrobial property can also be benefici$\mathrm{al}$, and ABS has the potential usage for preventing against various type bacterial pathogens. The experience in the relapsed leukemic transplant patient shows that ABS application can be used safely in oral mucositis controlled haemostatic and topical anti-infective effectiveness.

Exaggerated bleeding, particularly in patients with hereditary or acquired hemorrhagic diathesis, is a challenging problem in the clinic on a daily basis. Antithrombotic, procoagulant, and antifibrinolytic medications are frequently used for the management of bleeding. Ankaferd-induced formation of the protein network covers the entire physiological hemostatic process without unequally affecting any individual clotting factor in many pathobiological states..$^{1-3,5-31} \mathrm{ABS}$ may, therefore, be effective both in individuals with normal haemostatic parameters and in patients with deficient primary haemostasis and/or secondary haemostasis. After the approval of Ankaferd for the management of dental bleeding by Turkish Ministry of Health, ABS has been added to the protocols of prevention and treatment of exaggerated hemorrhage due to dental procedures in Turkey. In this study, controlling clinical critical bleeding states associated with deficiencies of either primary or secondary hemostasis have been examined retrospectively. The patients with bleeding diathesis about controlling critical bleedings that could not be controlled with standard anti-haemorrhagic methods, with topical ABS are herein presented. The observations in these patients are promising regarding the usage of ABS in anticoagulated patients and hereditary bleeding disorders such as clotting factor deficiencies. Future controlled trials shall be performed to fully elucidate the efficacy of ABS in those difficult clinical settings with hemorrhagic diathesis.

\section{REFERENCES}

1. Haznedaroglu IC. Molecular basis of the pleiotropic effects of ankaferd blood stopper. IUBMB Life 61: 290290, 2009.

2. Goker H, Haznedaroglu IC, Ercetin S, et al. Haemostatic actions of the folkloric medicinal plant extract, ankaferd blood stopper. Blood 110: 53b-53b, 2007.

3. Goker H, Haznedaroglu IC, Ercetin S, et al. Haemostatic actions of the folkloric medicinal plant extract ankaferd blood stopper (r). Journal of International Medical Research 36: 163-170, 2008.

4. Haznedaroglu IC. Time to take a healthier view of history. Nature 396: 108, 1998.

5. Haznedaroglu IC, Goker H. Haemostatic actions of the folkloric medicinal plant extract ankaferd blood stopper response. Journal of International Medical Research 36: 1448-1449, 2008.

6. Akar N, Demiralp DO, Haznedaroglu IC, Goker H. Functional proteomics of ankaferd blood stopper. ASH Annual Meeting Abstracts 112: 4103- , 2008.

7. Aydin S. Haemostatic actions of the folkloric medicinal plant extract ankaferd blood stopper (r). Journal of International Medical Research 37: 279-279, 2009.

8. Yilmaz E, Gulec S, Haznedaroglu IC, Akar N. Effects of ankaferd on huvec transcription factors and erythrocyte protein profile; in Haznedaroglu IC, Goker H, Ozdemir O, Kosar A, Firat H (eds): Ankaferd: Scientific perspectives and basic-clinical data. Istanbul, Naviga Publications, 2008, pp 60.

9. Arslan S, Haznedaroglu IC, Oz B, Goker H. Endobronchial application of ankaferd blood stopper to control profuse lung bleeding leading to hypoxemia and hemodynamic instability. Respir Med 2: 144-146, 2009.

10. Erçetin S, Haznedaroğlu IC, Kurt M, et al. Safety and efficacy of ankaferd bloodstopper $®$ in dental surgery and bleeding. UHOD 20: 1-5, 2010.

11. Koray M, Ergun S, Saruhanoglu A, Tanyeri $H$. Use of a new local haemostatic agent ankaferd blood stopper after surgical excision of eruption cyst: A case report. International Journal of Oral and Maxillofacial Surgery 38: 558-558, 2009.

12. Kurt M, Kacar S, Onal IK, et al. Ankaferd blood stopper as an effective adjunctive hemostatic agent for the management of life-threatening arterial bleeding of the digestive tract. Endoscopy 40 Suppl 2:E262, 2008.

13. Akgül T, Huri E, Ayyıldız A, et al. The histopathological effects of ankaferd bloodstopper $\AA$, a local medical plant extract, in mice penile fracture model: An experimental study. UHOD 19: 159-165, 2009.

14. Bilgili $\mathrm{H}$, Captug $\mathrm{O}$, Kosar $\mathrm{A}$, et al. Oral systemic administration of ankaferd blood stopper has no short-term toxicity in an "in vivo" rabbit experimental model. Clin Appl Thromb Hemost 16: 533-536, 2010. 
15. Bilgili H, Kosar A, Kurt M, et al. Hemostatic efficacy of ankaferd blood stopper $(r)$ in a swine bleeding model. Med Prin Pract 18: 165-169, 2009.

16. Cipil H, Kosar A, Kaya A, et al. In vivo hemostatic effect of the medicinal plant extract ankaferd blood stopper in rats pretreated with warfarin. Clin Appl Thromb Hemost 15: 270-276, 2009.

17. Huri E, Akgul T, Ayyildiz A, et al. Hemostatic role of a folkloric medicinal plant extract in a rat partial nephrectomy model: Controlled experimental trial. J Urology 181: 2349-2354, 2009.

18. Huri E, Akgül T, Ayyıldız A, et al. The evaluation of the blood stopping effect of ankaferd bloodstopper ${ }^{\circledR}$ in major renal trauma: An animal experimentation. UHOD 20: 206-211, 2010.

19. Karakaya K, Ucan HB, Tascilar O, et al. Evaluation of a new hemostatic agent ankaferd blood stopper in experimental liver laceration. J Invest Surg 22: 201-206, 2009.

20. Kosar A, Cipil HS, Kaya A, et al. The efficacy of ankaferd blood stopper in antithrombotic drug-induced primary and secondary hemostatic abnormalities of a rat-bleeding model. Blood Coagul Fibrin 20: 185-190, 2009.

21. Kurt M, Disibeyaz S, Akdogan M, et al. Endoscopic application of ankaferd blood stopper as a novel experimental treatment modality for upper gastrointestinal bleeding: A case report. American Journal of Gastroenterology 103: 2156-2158, 2008.

22. Kurt M, Oztas E, Kuran S, et al. Tandem oral, rectal, and nasal administrations of ankaferd blood stopper to control profuse bleeding leading to hemodynamic instability. Am J Emerg Med 27: 631 e631-631 e632, 2009.

23. Akkoc N, Akcelik M, Haznedaroglu I, et al. In vitro anti-bacterial activities of ankaferd blood stopper. International Journal of Laboratory Hematology 30: 95-95, 2008.

24. Akkoc N, Akcelik M, Haznedaroglu IC, et al. In vitro anti-bacterial activities of ankaferd medicinal plant extract. Turkiye Klinikleri Tip Bilimleri Dergisi 29: 410-415, 2009.

25. Fisgin NT, Cayci YT, Coban AY, et al. Antimicrobial activity of plant extract ankaferd blood stopper (r). Fitoterapia 80: 48-50, 2009.
26. Aktas A. Evaluation of the effects of ankaferd haemostatic plant extract on isolated rat vessel. UHOD 20: 156-162, 2010.

27. Albayrak $\mathrm{CU}$, Caliskan U. Haemostatic actions of the folkloric medicinal plant extract ankaferd blood stopper. Journal of International Medical Research 36: 1447-1448, 2008.

28. Dogan OF, Ozyurda U, Uymaz OK, et al. New anticoagulant agent for CABG surgery. European Journal of Clinical Investigation 38: 341-341, 2008.

29. Goker H, Cetinkaya D, Kilic E, et al. Anti-cancer activity of ankaferd blood stopper on osteosarcom (SAOS-2) cell lines in vitro; in Haznedaroglu I.C. GH, Ozdemir O, Kosar A, Firat $\mathrm{H}$ (ed Ankaferd: Scientific perspectives and basic-clinical data. Istanbul, Naviga Publications, 2008, pp 109.

30. Goker H, Kilic E, Cetinkaya D, et al. Anti-cancer activity of ankaferd on human colon cancer (CACO-2) in vitro; in Haznedaroglu IC, Goker H, Ozdemir O, Kosar A, Firat $\mathrm{H}$ (eds): Ankaferd: Scientific perspectives and basic-clinical data. Istanbul, Naviga Publications, 2008, pp 108.

31. Ibis M, Kurt M, Onal IK, Haznedaroglu IC. Successful management of bleeding due to solitary rectal ulcer via topical application of ankaferd blood stopper. J Altern Complem Med 14: 1073-1074, 2008.

\section{Correspondence}

Dr. Mehmet TURGUT

Samsun 19 Mayıs Üniversitesi Tıp Fakeltesi

Hematoloji Bilim Dalı

Samsun / TURKEY

Tel: (+90.362) 3121919 / 2409

Fax: (+90.362) 4576041

e-mail: turgutmehmet@gmail.com 